\title{
PENGEMBANGAN MODEL PERMAINAN TRADISIONAL UNTUK TRAUMA HEALING PASCA BENCANA PADA ANAK USIA DINI
}

\author{
Reza Edwin Sulistyaningtyas ${ }^{1}$ \\ Universitas Muhammadiyah Magelang
}

\begin{abstract}
Indonesia is a country that is prone to natural disasters. The impact of a natural disaster can happen to anyone, be it adults or younger children. Especially for young children to natural disasters is a phenomenon that is less biased understood by children, so if a natural disaster that happens the child will be prone to trauma. Trauma experienced by early children can handled, one of them using play therapy. Types of play activities that can be using for play therapy is the traditional game. This study aims to: (1)develop the design of traditional games model for post-disaster trauma healing in early childhood and (2) knowing the appropriate by expert of the traditional games model for post-disaster trauma healing in early childhood. This type of research is the research and development $(R \& D)$. -ADDIE development model is employed in this study, through three stages - which are: analyze, design and development. The technique of collecting data used interviews and questionnaires. Data analysis used quantitative analysis by using the average as a measurement to determine the quality of the product. Based on the evaluation -from materials and media experts shows that the feasibility of the media obtained an average score 3.09 (good) and the appropriateness of the material obtained a score of 3.9 (very good).
\end{abstract}

Keyword: trauma healing, early childhood, traditional games, natural disaster, play therapy.

\begin{abstract}
Abstrak: Indonesia merupakan negara yang rawan terjadi bencana alam. Dampak terjadinya bencana alam dapat terjadi pada siapa saja, baik itu orang dewasa maupun anak usia dini. Terutama bagi anak usia dini bencana alam merupakan fenomena yang kurang bisa dipahami oleh anak sehingga jika bencana alam itu terjadi anak akan rentan terkena trauma. Trauma yang dialami oleh anak usia dini dapat ditangani, salah satunya dengan menggunakan terapi bermain. Jenis kegiatan bermain yang dapat digunakan untuk play terapi yaitu permainan tradisional. Penelitian ini bertujuan untuk: (1) mengembangkan desain model permainan tradisional untuk trauma healing pasca bencana pada anak usia dini dan (2) mengetahui kelayakan model permainan tradisional untuk trauma healing pasca bencana pada anak usia din. Jenis penelitian ini adalah penelitian dan pengembangan (Research \& Development). Model pengembangan menggunakan ADDIE, namun dalam penelitian ini sampai pada tahap 3 yaitu: analyze, design dan development. Teknik pengumpulan data dengan menggunakan wawancara dan angket. Analisis data menggunakan analisis kuantitatif dengan menggunakan rata-rata sebagai ukuran untuk mengetahui kualitas produk. Berdasarkan penilaian dari ahli materi dan media diperoleh hasil untuk kelayakan media diperoleh skor rata-rata 3.09 (baik) dan kelayakan materi diperoleh skor 3.9 (sangat baik).
\end{abstract}

Kata Kunci: Trauma healing, Anak usia dini, Permainan tradisional, Bencana alam, terapi bermain.

'Universitas Muhammadiyah Magelang, Email: reza.edwin国ummgl.ac.id 


\section{PENDAHULUAN}

Indeks Risiko Bencana/IRB (BNPB, 2019) menyebutkan bahwa terdapat 12 jenis ancaman bencana di Indonesia dan tidak ada kabupaten dan kota yang bebas dari ancaman bencana. Hal tersebut sesuai dengan kondisi negara Indonesia yang merupakan negara rawan terjadi bencana. Pada tahun 2019 menurut Sutopo sebagai Kepala Pusat Data Informasi dan Hubungan Masyarakat Badan Nasional Penanggulangan Bencana menjelaskan bahwa kejadian bencana meningkat sebesar $7,2 \%$ dan juga jumlah korban jiwa bencana mengalami kenaikan sebesar 192\% dibandingkan tahun sebelumnya (Dewi, 2019). Berdasarkan sebaran kejadian bencana per provinsi maka bencana paling banyak terjadi di Jawa Tengah (472 kejadian), Jawa Barat (367 kejadian), Jawa Timur (245 kejadian), Sulawesi Selatan (70 kejadian) dan Aceh (51 kejadian) (BNPB, 2019).

Dampak yang ditimbulkan akibat bencana tidak hanya memakan korban jiwa manusia yang banyak, kerusakan lingkungan, dan kerugian harta benda, tetapi juga dampak psikologis baik pada anak-anak mapun orang dewasa. Perasaan tidak tenang, kegelisahan, trauma, dan ketakutan merupakan hasil yang ditimbulkan dari dampak psikologis setelah bencana terjadi terutama bagi anak usia dini. Deters (2011) menyatakan bahwa anak-anak usia 0-8 tahun memiliki persentase yang tinggi terhadap dampak yang ditimbulkan dari bencana yang terjadi. Namun, seringkali dampak psikologis pada anak usia dini setelah bencana tidak teridentifikasi dengan baik (Kar, 2009).

Dengan demikian diperlukan adanya penanganan terhadap korban bencana terutama pada anak usia dini. Penanganan trauma pada anak usia dini harus disesuaikan dengan karakteristik anak usia dini. Masa anak usia dini merupakan masa bermain sehingga dalam penanganan trauma melalui terapi bermain. Bermain dapat digunakan dengan baik sebagai media terapi anakanak (Kar, 2009). Hal tersebut juga didukung dengan penelitian yang dilakukan oleh Mukhadiono, dkk (2016) menunjukkan bahwa terapi bermain dapat dijadikan sebagai salah satu program penanganan dampak psikologis anak korban bencana. Melalui bermain anak dapat mengekspresikan perasaan takut, sedih, gelisah, dan trauma. Salah satu kegiatan bermain yang dapat dilakukan untuk menangani trauma adalah permainan tradisional.

Permainan tradisional merupakan salah satu jenis kegiatan bermain yang saat ini sudah jarang dimainkan oleh anak-anak. Jika dipelajari lebih mendalam permainan tradisional sangat memiliki banyak manfaat terutama untuk menstimulasi perkembangan anak usia dini. Diantaranya adalah meningkatkan keterampilan gerak dasar, meningkatkan keterampilan sosial anak meliputi kooperatif, tanggung jawab, empati, kontrol diri dan percaya diri dan melalui permainan tradisional anak menjadi lebih kreatif (Rahmawati, 2009).

Beberapa penelitian terdahulu yang menerapkan terapi bermain untuk menangani trauma setelah bencana belum memperhatikan kegiatan bermain yang disesuaikan dengan budaya setempat. Oleh karena itu peneliti tertarik untuk mengembangkan permainan tradisional sebagai alternatif untuk menangani trauma setelah bencana. Merujuk pada data provinsi yang paling banyak terjadi bencana yaitu pada provinsi Jawa Tengah maka dalam penelitian ini memfokuskan pada daerah Jawa Tengah tepatnya di kabupaten Magelang.

\section{TINJUAN PUSTAKA Trauma}

Trauma merupakan tekanan emosional pada seseorang akibat dari bencana, kekerasan, kejahatan dan kejadian yang mendadak. Trauma juga merupakan salah satu luka psikologis 
yang dapat menurunkan daya intelektual, emosional, dan perilaku (Hatta, 2016). Trauma berarti luka atau kekagetan (syok/shock) yang disebabkan oleh peristiwa yang sangat menekan, terjadi secara tiba-tiba dan di luar kontrol/kendali seseorang, bahkan seringkali membahayakan kehidupan atau mengancam jiwa (Martam, 2009).

Truma yang terjadi setelah adanya bencana akan dirasakan oleh orang dewasa dan anak-anak. Namun, trauma yang dirasakan oleh anak-anak berbeda dengan orang dewasa. Anak-anak korban bencana cenderung lebih mudah mengalami trauma dibandingkan orang dewasa karena anak-anak belum memiliki kematangan identitas diri dan kemampuan koping terhadap stres masih terbatas sehingga jika trauma psikis terjadi pada anak-anak biasanya akan terjadi penghentian perkembangan emosional (Kaplan dkk, 1997 dalam Safitri, 2018).

\section{Permainan tradisional}

Dockett dan Fleer (1999) menyatakan bahwa bermain merupakan kebutuhan bagi anak, karena melalui bermain anak akan memperoleh pengetahuan yang dapat mengembangkan kemampuan dirinya. Bermain dapat meningkatkan kemampuan anak dalam berinteraksi dengan teman sebaya dan memungkinkan anak untuk mengembangkan keterampilan sosial. Selain itu bermain dapat menjadi kegiatan anak untuk menyalurkan perasaan dan memahami aturan dalam permainan. Anak pun dapat berlatih untuk menunggu giliran dan belajar bernegosiasi dengan teman sebaya tentang aturan dalam suatu permainan.

Salah satu fungsi bermain yaitu untuk memberikan terapi pada anak yang mengalami guncangan psikis yang diakibatkan karena bencana. Terapi bermain menekankan pada kekuatan permainan sebagai alat untuk membantu klien dalam rangka mencegah dan mengatasi persoalan psikisnya serta membantu pencapaian pertumbuhan dan perkembangan sesuai dengan tugas perkembangannya secara optimal (Nawangsih, 2014). Terapi bermain yang diterapkan sebisa mungkin memenuhi beberapa konsep dasar permainan yang dapat digunakan dalam terapi bermain. Konsep dasar yang dapat digunakan pada terapi bermain adalah mengacu pada pandangan sebagai berikut (Nawangsih, 2014):

1. Bermain adalah salah satu cara yang dapat digunakan dalam memahami dunia anak-anak

2. Aspek perkembangan dalam kegiatan bermain merupakan cara anak dalam menemukan dan mengekplorasi identitas diri mereka

3. Anak dapat melakukan eksperimen dengan berbagai pilihan imajinatif dan terhindar dari konsekuensi seperti ketika di dunia nyata

4. Permainan pada situasi dan kondisi yang tepat dapat bermakna sebagai kegiatan fisik sekaligus sebagai terapi

Bishop \& Curtis (2005) mendefinisikan permainan tradisional sebagai permainan yang telah diturunkan dari satu generasi ke generasi berikutnya dengan permainan tersebut mengandung nilai "baik" dan "positif". Permainan tradisional berasal dari generasi sebelumnya kemudian diwariskan ke generasi muda melalui lisan, suara atau praktik (Ghipit, Abdullah, Musa, Kosni \& Maliki, 2017, McKinty, 2013). Sependapat dengan hal tersebut Mulyani (2016) menyatakan bahwa permainan tradisional adalah suatu permainan warisan dari nenek moyang yang wajib dan perlu dilestarikan karena mengandung nilai-nilai kearifan lokal. Melalui permainan tradisional dapat meningkatkan berbagai aspek perkembangan anak.

Permainan tradisional anak-anak pada masing-masing daerah dan masyarakat dibentuk oleh budaya lokal 
dan lingkungan setempat (Hassan dkk, 2013). Permainan tradisional dapat digunakan sebagai terapi terhadap anak yang memerlukan kondisi tersebut. Saat bermain, anak-anak akan melepaskan emosinya. Mereka berteriak, tertawa, dan bergerak (Rahmawati, 2009). Selain itu dari hasil penelitian terdahulu menyatakan bahwa melalui permainan tradisional dapat memberikan pengaruh yang positif terhadap sosialisasi (pertemanan dan toleransi) antar anak (Kovacevic \& Opic, 2014; Petrovska, Sivevska \& Cackov, 2013).

\section{METODOLOGI PENELITIAN}

Penelitian ini menggunakan jenis penelitian pengembangan (research and development) dengan model ADDIE yang berorientasi pada produk yang dihasilkan. Metode yang dilakukan pada penelitian ini melalui tahapan Analyze (menganalisis), Design (mendesain) dan Development (mengembangkan).

Validator media dan materi dilakukan oleh expert judgement dari dosen PAUD FKIP Universitas Muhammadiyah Magelang.

\section{Teknik Analisis Data}

Teknik analisis data yang digunakan yaitu menggunakan analisis data kuantitatif. Data uji ahli berdasarkan skala penilaian dianalisis secara kuantitatif dengan menggunakan penskoran. Data kuantitatif diperoleh melalui penskoran instrumen panduan permainan oleh ahli. Data kuantitatif tersebut kemudian dikonversikan ke data kualitatif untuk mengetahui kualitas produk. Konversi yang dilakukan terhadap data sebagai berikut:

Tabel 1. Hasil konversi rata-rata skor menjadi skala 4

\begin{tabular}{ccc}
\hline \multicolumn{2}{c}{ Interval skor } & Deskripsi \\
\hline$X \geq \bar{X}+1.5 S B x$ & $\mathrm{X} \geq 3.25$ & Sangat Baik \\
$\bar{X}+1.5 S B x>X \geq \bar{X}$ & $3.25>\mathrm{X} \geq 2.5$ & Baik \\
$\bar{X}>X \geq \bar{X}-1.5 S B x$ & $2.5>\mathrm{X} \geq 1.75$ & Kurang \\
$X \leq \bar{X}-1.5 S B x$ & $\mathrm{X} \leq 1.75$ & Sangat kurang \\
\hline
\end{tabular}

\section{HASIL PENELITIAN DAN PEMBAHASAN \\ 1. Analyze (Analisis Kebutuhan)}

Analisis kebutuhan dilakukan dengan menggunakan wawancara dan angket. Pengumpulan data menggunakan wawancara dilakukan pada 1 staff BPBD (Badan Penanggulangan Bencana Daerah) dan 10 guru TK, hal ini bertujuan untuk mengetahui informasi mengenai daerah rawan bencana di Magelang dan penanganan trauma pasca bencana pada anak usia dini yang pernah dilakukan guru. Berdasarkan hasil wawancara yang dilakukan pada staff BPBD menyatakan bahwa bencana yang pernah terjadi di Magelang yaitu erupsi dan tanah longsor. Pada bencana skala besar yaitu erupsi gunung Merapi dan frekuensi paling sering adalah tanah longsor. Bencana alam yang terjadi pada 5 tahun terakhir ini paling besar terjadinya tanah longsor dan banjir bandang di desa Sambungrejo Magelang. Banjir bandang dan tanah longsor yang terjadi diakibatakan karena intensitas curah hujan yang tinggi. Akibatnya terdapat 1 sekolah PAUD yang hanyut terbawa air karena dekat dengan sungai. Oleh karena itu pihak BPBD Magelang menyarankan untuk dapat melaksanakan penelitian di daerah tersebut.

Selanjutnya analisis kebutuhan didukung dengan survey menggunakan angket yang disebar ke 10 guru yang sekolahnya pernah mengalami bencana alam. Pada angket tersebut menggali informasi mengenai penanganan trauma yang pernah dilakukan guru ketika terjadi bencana. Berdasarkan hasil survey yang dilakukan diketahui bahwa sebanyak $70 \%$ guru belum pernah melaksanakan penanganan trauma setelah terjadi bencana.

Ketika guru mengisi survei atas pertanyaan mengenai berbagai macam model permainan yang dapat digunakan untuk menangani trauma pasca bencana pada anak usia dini yang dibutuhkan 
guru. Sebanyak $60 \%$ guru menjawab sangat membutuhkan dan $40 \%$ menjawab membutuhkan berbagai model permainan untuk untuk menangani trauma pada anak usia dini pasca bencana. Jenis model permainan yang tidak pernah digunakan guru untuk menangani trauma pasca bencana pada anak usia dini adalah permainan traidisional. Hal tersebut dibuktikan dengan hasil survey yang menyatakan sebanyak 60\% guru tidak pernah menggunakan permainan traidisional.

Melalui pengembangan model permainan traidional dapat memudahkan guru dalam menerapkan sehingga penanganan trauma pasca bencana pada anak usia dini dapat ditangani secara tepat. Oleh karena itu hasil pengumpulan data mengenai analisis kebutuhan dan kajian teori dijadikan acuan melakukan analisis dalam merumuskan konsep pengembangan awal.

\section{Design (Desain) dan Develop (pengembangan)}

Berdasarkan pada tahap analisis maka produk yang akan dikembangkan dalam penelitian ini adalah buku model permainan tradisional untuk trauma healing pasca bencana pada anak usia dimi. Adapun komponen-komponen yang akan dikembangkan meliputi: pendahuluan, permainan traidisional yang telah dimodifikasi (bentengan bola, ular naga dan egrang kaleng) dan alat penilaian/kuisioner trauma.

Selain itu pada tahap desain dibuat instrumen validasi buku model permainan tradisional berupa angket dengan skala Likert. Angket terdiri dari 4 pilihan jawaban, yaitu 1 (sangat kurang), 2 (kurang, 3 (baik) dan 4 (sangat baik) yang digunakan untuk menilai kualitas kelayakan buku yang dikembangkan. Instrumen validasi terbagi menjadi tiga yaitu instrumen validasi ahli media, ahli materi dan pengguna. Pada instrumen ahli media terdapat tiga komponen kualitas pada angket ini, yaitu: kualitas isi dan tujuan, kualitas instruksional dan kualitas teknis. Selanjutnya instrumen ahli materi terdapat tiga komponen kelayakan, yaitu: kelayakan isi, kelayakan bahasa dan kelayakan penyajian. Instrumen yang ketiga yaitu untuk pengguna (guru) terdapat tiga komponen, yaitu: kelayakan isi, kelayakan penyajian dan kualitas teknis.

Pada uji kelayakan materi menilai mengenai kelayakan isi, kebahasaan dan penyajian buku model permainan tradisional menggunakan angket penilaian pada instrumen yang ada. Setelah memperoleh hasil kelayakan dari ahli materi, berikutnya hasil penilaian tersebut dikonsultasikan dengan tabel konversi interval rerata skor (4 skala).

Hasil konversi digunakan untuk menyatakan kriteria penilaian dari skor rata-rata yang didapat oleh ahli. Setelah diperoleh hasil konversi selanjutnya menghitung skor rata-rata pada setiap indikator ahli materi. Berikut hasil validasi ahli materi yang diperoleh:

Tabel 2. Rata-rata penilaian validasi ahli materi

\begin{tabular}{clll}
\hline $\mathbf{N}$ & Indikator & $\begin{array}{l}\text { Skor } \\
\text { rata-rata }\end{array}$ & $\begin{array}{l}\text { Kriteria } \\
\text { penilaian }\end{array}$ \\
\hline 1 & Kelayakan Isi & 3.7 & $\begin{array}{l}\text { Sangat } \\
\text { Baik } \\
\text { Sangat }\end{array}$ \\
2 & Kebahasaan & 4 & $\begin{array}{l}\text { Baik } \\
\text { Sangat } \\
\text { Baik } \\
\text { Sangat } \\
\text { Baik }\end{array}$ \\
\hline
\end{tabular}

Berdasarkan pada penilaian oleh validasi ahli materi didapatkan skor ratarata 3.9. Selanjutnya skor rata-rata tersebut dikonversi dengan tabel konversi berada pada rentang $\mathrm{X}>3.25$ dengan kriteria "sangat baik". Selanjutnya jika dilihat per-indikator untuk indikator kelayakan isi didapatkan rata-rata 3.7 dengan kriteria "sangat baik". Pada indikator kebahasaan didapatkan rata-rata 4 dengan kriteria "sangat baik". Terakhir pada indikator penyajian didapatkan ratarata 4 dengan kriteria "sangat baik". Kesimpulan yang diperoleh dari hasil 
penilaian ahli materi terhadap buku panduan permainan tradisional yaitu layak digunakan dengan revisi sesuai saran.

Selanjutnya uji kelayakan media menilai mengenai kualitas isi dan tujuan, kualitas pembelajaran dan kualitas teknik buku panduan permainan tradisional dengan menggunakan angket penilaian pada instrumen yang ada. Berikut hasil validasi ahli media yang diperoleh:

Berdasarkan pada penilaian oleh validasi

\begin{tabular}{llll}
\hline $\mathbf{N}$ & Indikator & $\begin{array}{l}\text { Skor rata- } \\
\text { rata }\end{array}$ & $\begin{array}{l}\text { Kriteria } \\
\text { Penilaian }\end{array}$ \\
\hline 1 & $\begin{array}{l}\text { Kualitas isi } \\
\text { dan tujuan }\end{array}$ & 3 & Baik \\
2 & $\begin{array}{l}\text { Kualitas } \\
\text { pembelajaran } \\
\text { Kualitas } \\
\text { teknik } \\
\text { Total Rata- } \\
\text { rata }\end{array}$ & 3.27 & Baik \\
& $\begin{array}{l}\text { Sangat } \\
\text { Baik } \\
\text { Baik }\end{array}$ \\
\hline
\end{tabular}

ahli media didapatkan skor rata-rata 3.09. Selanjutnya skor rata-rata tersebut dikonversi dengan tabel konversi berada pada rentang $3.25>X \geq 2.5$ dengan kriteria "baik". Selanjutnya jika dilihat per-indikator untuk indikator kualitas isi dan tujuan didapatkan rata-rata 3 dengan kriteria "baik". Pada indikator kualitas pembelajaran didapatkan rata-rata 3 dengan kriteria "baik". Terakhir pada indikator kualitas teknik didapatkan ratarata 3.27 dengan kriteria "sangat baik"..

\section{KESIMPULAN}

Simpulan Berdasarkan hasil penelitian dan pengembangan yang dilaksanakan dapat disimpulkan bahwa model permainan tradisonal dikembangkan untuk penanganan trauma pasca bencana pada anak usia dini. Di dalam buku model permainan tradisional membahas kajian tentang trauma, terapi bermain dan model permainan tradisional. Model permainan tradisional yang dikembangkan meliputi egrang kaleng, bentengan bola dan ular naga.

Model permainan tradisional untuk trauma healing pasca bencana pada anak usia dini telah divalidasi oleh ahli materi dan ahli media. Berdasarkan hasil penilaian oleh ahli materi diperoleh hasil yang meliputi kelayakan isi dinilai "sangat baik", kebahasaan mendapatkan nilai "sangat baik" dan penyajian memperoleh nilai "sangat baik". Berdasarkan perolehan nilai tersebut secara keseluruhan Model permainan tradisional untuk trauma healing pasca bencana pada anak usia dini menurut ahli materi dinyatakan layak dengan kategori "sangat baik". Selanjutnya penilaian dari ahli media didapatkan hasil yang meliputi kualitas isi dan tujuan mendapatkan nilai "baik", kualitas pembelajaran memperoleh nilai "baik" dan kualitas teknik dinilai "sangat baik". Berdasarkan perolehan nilai tersebut secara keseluruhan Model permainan tradisional untuk trauma healing pasca bencana pada anak usia dini menurut ahli media dinyatakan layak dengan kategori "baik". Penelitian lebih lanjut dapat menguji efektivitas dari model permainan tradisional untuk trauma healing pada anak usia dini di daerah rawan bencana. Selain itu juga dapat merumuskan bagaimana mitigasi bencana agar anak usia dini memiliki kemampuan untuk menyelamatkan diri dari bencana.

\section{DAFTAR PUSTAKA}

Berisi Bishop, J.C. \& Curtis, M. 2005.Permainan Anak-Anak Zaman Sekarang di Sekolah Dasar. Editor: Yovita Hadiwati. Jakarta: PT. Grasindo

BNPB. (2019). 1586 kejadian bencana menyebabkan 438 jiwa meninggal dan hilang terjadi selama tahun 2019.

(Online)

https://www.bnpb.go.id/1586kejadian-bencana-menyebabkan438-jiwa-meninggal-dan-hilangterjadi-selama-tahun-2019. Diakses pada tanggal 21 Juni 2019.

Deters, Lisa. (2011). Promoting and Supporting Holistic Development: Baby Tents in Post-earthquake 
Haiti. Australia: Macquarie University

Dewi, R. K. (2019). Data bencana BNPB pada 2019, 1.538 Kejadian dan 325 korban meninggal. (Online). https://nasional.kompas.com/read/2 019/04/30/19322341/ databencana-bnpb-pada 2019-1538kejadian-dan-325-korbanmeninggal. Diakses pada tanggal 22 Juni 2019

Dockett, S. \& Fleer, M. (1999). Play and Pedagogy in Early Childhood Bending the Rules. Australia: Harcourt Brace.

Ghipit@ Charles, M. A., Abdullah, M. R., Musa, R. M., Kosni, N. A., \& Maliki, A. B. H. M. (2017). The effect of traditional games intervention programme in the enhancement school-age children's motor skills: A preliminary study. Health, Movement \& Exercise. 6(2), 157-169. http://dx.doi.org/10.15282/mohe.v6 i2. 142

Hassan, F., dkk. (2013). Introduction Traditional Games Honing Skills and Dexterity (Promoting peace and social cohesion through heritage education). Islamabad: UNESCO.

Hatta, K. (2016). Trauma dan Pemulihannya (Sebuah Kajian Berdasarkan Kasus Pasca Konflik dan Tsunami). Banda Aceh: Dakwah Ar-Raniry Press.

Kovačević, T., \& Opić, S. (2014). Contribution of Traditional Games to the Quality of Students Relations and Frequency of Students' Socialization in Primary Education, 16(1), 95-112.

Kar, N. (2009). Psychological impact of disasters on children: review of assessment and interventions. World J Pediatr, 5 (1), 5-11. doi:10.1007/s12519-009-0001-x
Martam, I.S. (Desember 2009). Mengenali trauma pasca bencana. Newsletter Pulih, 14, 1-4.

McKinty, J. (2013) From playground to patient: reflections on a traditional games project in a pædiatric hospital. International Journal of Play. 2(3), 187-201. DOI:10.1080/21594937.2013.8520 53

Mukhadiono, Subagyo;W \& Wahyudi. (2016). Pemulihan ptsd anak-anak korban bencana tanah longsor dengan play therapy. Jurnal Keperawatan Soedirman. 11 (1),23-30.

jks.fikes.unsoed.ac.id/index.php/jks /article/view/643

Mulyani, N. (2016). Super Asyik Permainan Tradisional Anak Indonesia. Yogyakarta: DIVA Press

Nawangsih, E. (2014). Play therapy untuk anak-anak korban bencana alam yang mengalami trauma (post traumatic stress disorder/ptsd). Psympathic, Jurnal Ilmiah Psikologi. 1(2), 164 - 178. https://journal.uinsgd.ac.id/index.p hp/psy/article/view/475

Petrovska, S., Sivevska, D., \& Cackov, O. (2013). Role of the Game in the Development of Preschool Child. Procedia - Social and Behavioral Sciences, 92(Lumen), 880-884. https://doi.org/10.1016/j.sbspro.201 3.08.770

Rahmawati, A.(2009). Permainan Tradisional Untuk Anak Usia 4-3 Tahun. Bandung: Sandiarta Sukses.

Safitri, N. (2018). Crisis and disaster counseling: peran konselor terhadap korban yang selamat dari bencana alam. Educational Guidance and Counseling Development Jounal, 1(2), 66-76. http://ejournal.uinsuska.ac.id/index.php/EGCDJ/articl e/view/6053/3626 